\title{
sciendo
}

RESEARCH PAPERS FACULTY OF MATERIALS

SCIENCE AND TECHNOLOGY IN TRNAVA

SLOVAK UNIVERSITY OF TECHNOLOGY

IN BRATISLAVA

2018, Volume 26, Number 42

DOI 10.2478/rput-2018-0022

\section{INFLUENCE OF END MILL HELIX ANGLE ON SURFACE QUALITY OF ALUMINIUM THIN-WALLED PARTS}

\author{
Ivan BURANSKÝ, Matej BRAČÍK, Vladimír ŠIMNA \\ SLOVAK UNIVERSITY OF TECHNOLOGY IN BRATISLAVA, \\ FACULTY OF MATERIALS SCIENCE AND TECHNOLOGY IN TRNAVA, \\ INSTITUTE OF PRODUCTION TECHNOLOGIES, \\ UliCA JÁNA BotTu 2781/25, 91724 TRNAVA, SLOVAK REPUBliC \\ e-mail: ivan.buransky@stuba.sk,matej.bracik@stuba.sk, vladimir.simna@stuba.sk \\ Received: 01.06.2018, Accepted: 29.06.2018, Published: 19.09.2018
}

\begin{abstract}
This paper deals with the influence of the end mill helix angle on the flatness and surface quality of aluminium (EN AW 6082) thin-walled parts. The three teeth solid end mills of 12 mm diameter with same and different helix angle of third tooth were designed. The tests were performed using the HSC 105 linear CNC machine and following cutting parameters: cutting speeds (800, 100 and $\left.1200 \mathrm{~m} . \mathrm{min}^{-1}\right)$, feed per tooth $(0.12 \mathrm{~mm}$ ), cutting depth (for roughing 10 $\mathrm{mm}$ and for finishing $5 \mathrm{~mm}$ ). Evaluation of surface quality of the processed thin-walled parts shows that the helix angle of the end mills has a significant influence on the surface quality of the thin-walled parts. The best results were obtained in the case of end mill with different $35^{\circ}$ helix angle of third tooth and cutting speed 1000 m.min-1.
\end{abstract}

Key words

Milling, helix angle, aluminium thin-walled parts, 3D scanning, colour deviation map, flatness

\section{INTRODUCTION}

Thin-walled parts are widely used in the aviation, aeronautics, automotive and energetic industry. Due to the shape and low rigidity the thin-walled parts can be easily deformed during the milling process (1). The feature of a thin-walled part is to change the workpiece dynamic structure due the change in its geometrical shape. The challenge is in the creation of thin-walled sections. During the machining process, the workpiece undergoes deflection due the application of external forces caused by milling process (2).

For milling of thin walled parts, High Speed Cutting (HSC) is the most widened technology. A thin-walled part has lower thickness than height (3). During milling of thinwalled parts regenerative chatter vibrations are generated. The chatter is one of the major limitations in milling operations causing poor quality, reduced productivity (4). The regenerative chatter vibrations can be eliminated in several ways. The first way is the use of 
stability lobes diagrams to predict the regenerative chatter in milling $(5,6)$. The second way is the appropriate machining strategy (material removal way) of the thin-walled parts. An effective machining strategy has a significant impact on the surface quality of the thin-walled parts $(7,8)$. The third way is the use of end mills with variable pitch $(9,14,15)$ and variable helix angle (4). The fourth method is the use of the sandwich elements $(10,13)$ or the use workpiece or tool support (11). In this paper, the effect of the end mill helix angle on the flatness and surface quality of aluminium (EN AW 6082) thin-walled parts was studied.

\section{MATERIALS AND METHODOLOGY OF EXPERIMENTS}

Three solid end mills with regular pitch were designed using Numrotoplus software. Table 1 shows designed parameters of end mills and Fig. 1 shows CAD model of designed mill. The difference between each designed end mill was that the third tooth of each end mills has different helix angle. So that the one end mill of $30^{\circ}$ helix angle for all three teeth was designed and further two end mills were designed where helix angle of third tooth was $25^{\circ}$ and $35^{\circ}$, respectively. By variation of the third teeth helix angle the position of third cutting edge varies in regard of the distance from the tip of end mill (Fig. 2). For keeping same cutting edges width and clearance land width the parameters of flutes and reliefs were adjusted based on 2D and 3D simulation of Numrotoplus software. The end mills were made of cemented carbide of K20 grade and they were manufactured using WZS 60 Reinecker $\mathrm{CNC}$ grinding machine.

\begin{tabular}{|l|l|}
\hline \multicolumn{2}{|l|}{ Table 1: Parameters of designed end mills } \\
\hline Parameter of end mill & Value \\
\hline Diameter $-\mathrm{dm}_{\mathrm{m}}$ & $12 \mathrm{~h} 6 \mathrm{~mm}$ \\
\hline Diameter $-\mathrm{D}_{\mathrm{c}}$ & $11.95 \mathrm{~mm}$ \\
\hline Diameter- $\mathrm{D}_{\mathrm{n}}$ & $11 \mathrm{~mm}$ \\
\hline Length $-\mathrm{l}_{2}$ & $82.5 \mathrm{~mm}$ \\
\hline Length $-\mathrm{l}_{3}$ & $45 \mathrm{~mm}$ \\
\hline Max. depth of cut - $\mathrm{a}_{\text {pmax }}$ & $20 \mathrm{~mm}$ \\
\hline Pitch and division angle & $120-120-120^{\circ}$ \\
\hline Teeth number - $\mathrm{z}$ & 3 \\
\hline Helix angle & $30^{\circ}-30^{\circ}-30^{\circ}$ \\
\hline & $30^{\circ}-30^{\circ}-25^{\circ}$ \\
\hline & $30^{\circ}-30^{\circ}-35^{\circ}$ \\
\hline Rake angle & $10^{\circ}$ \\
\hline Relief angle & $10^{\circ}$ \\
\hline & \\
\hline
\end{tabular}




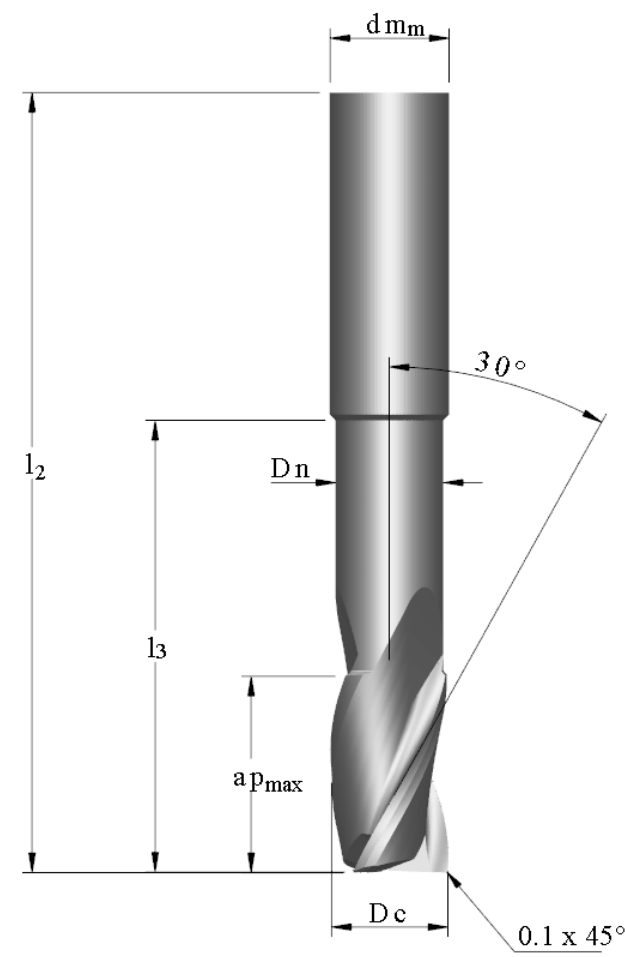

Fig. 1 CAD model of designed end mill

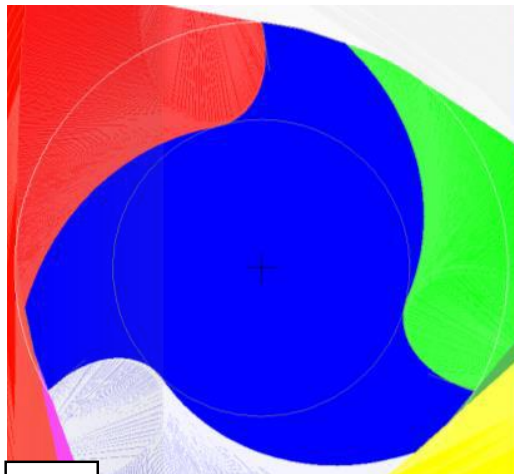

a)

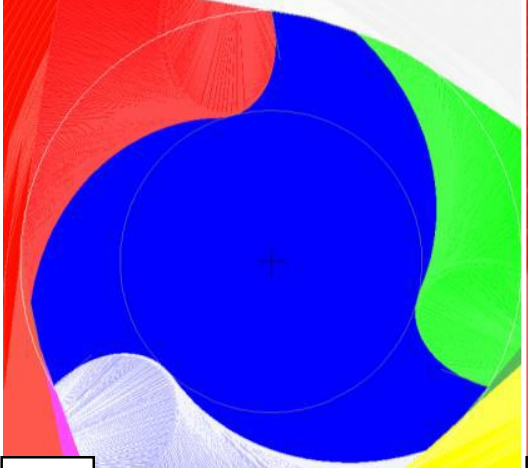

d)
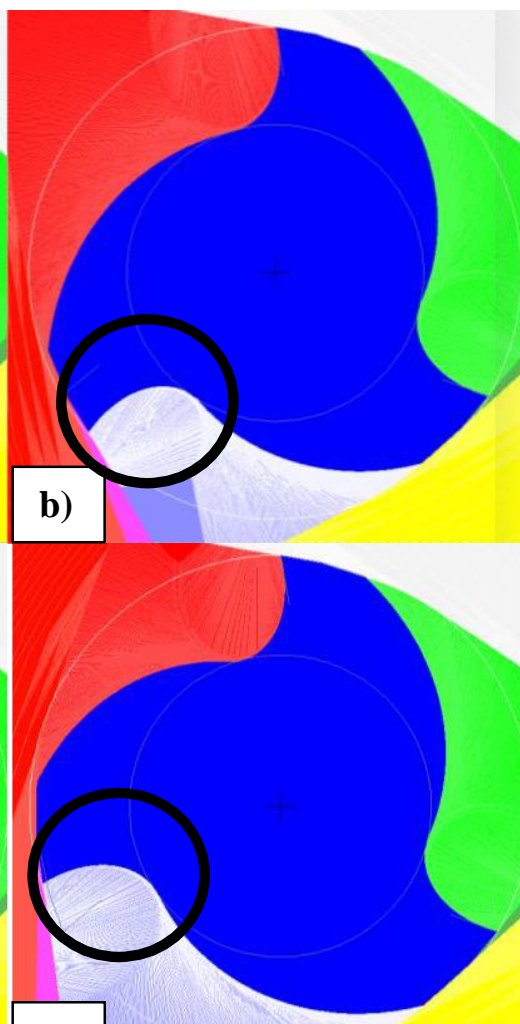

e)
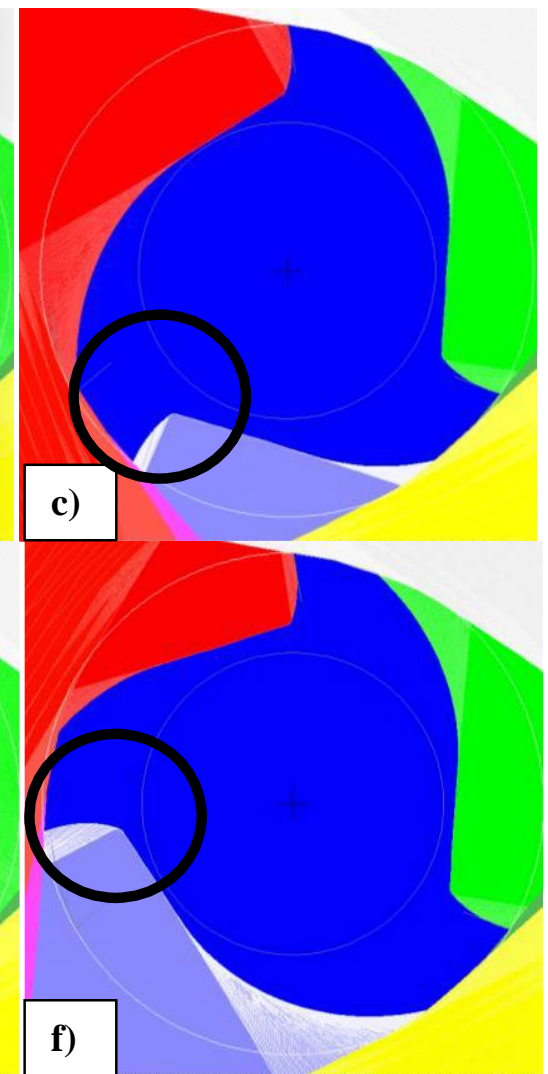

Fig. 2 Cross sections of end mill with $25^{\circ}$ helix angle of third tooth in $2 D$ simulation $0.1 \mathrm{~mm}(\mathrm{a})$, $10 \mathrm{~mm}(\mathrm{~b})$ and $20 \mathrm{~mm}(\mathrm{c})$ from the tip; cross sections of end mill with $35^{\circ}$ helix angle of third tooth in $2 \mathrm{D}$ simulation $0.1 \mathrm{~mm}(\mathrm{~d}), 10 \mathrm{~mm}(\mathrm{e})$ and $20 \mathrm{~mm}(f)$ from the tip 
The workpiece material was EN AW 6082 aluminium alloy. Tables 2 and 3 show the chemical composition and physical-mechanical properties of EN AW 6082 alloy. It is known that the machinability of the material is good. The blank dimensions were $80 \times 80 \times 10 \mathrm{~mm}$. Fig. 3 shows clamping of the blank in the machining vice. The overhang of the blank was 56 $\mathrm{mm}$.

\begin{tabular}{|c|c|}
\hline \multicolumn{2}{|c|}{$\begin{array}{l}\text { Table 2: Chemical composition } \\
\text { of EN AW } 6082\end{array}$} \\
\hline Chemical Element & $\%$ Present \\
\hline Manganese (Mn) & $0.40-1.00$ \\
\hline Iron $(\mathrm{Fe})$ & $0.0-0.50$ \\
\hline Magnesium $(\mathrm{Mg})$ & $0.60-1.20$ \\
\hline Silicon $(\mathrm{Si})$ & $0.70-1.30$ \\
\hline Copper $(\mathrm{Cu})$ & $0.0-0.10$ \\
\hline Zinc (Zn) & $0.0-0.20$ \\
\hline Titanium (Ti) & $0.0-0.10$ \\
\hline Chromium $(\mathrm{Cr})$ & $0.0-0.25$ \\
\hline Other (Each) & $0.0-0.05$ \\
\hline Other (Total) & $0.0-0.15$ \\
\hline Aluminium & Balance \\
\hline
\end{tabular}

Table 3: Physical and mechanical properties of AW 6082

\begin{tabular}{|l|l|}
\hline Property & Value \\
\hline Density & $2.70 \mathrm{~g} / \mathrm{cm}^{3}$ \\
\hline Melting Point & $555^{\circ} \mathrm{C}$ \\
\hline Thermal Expansion & $24 \times 10^{\wedge}-6 / \mathrm{K}$ \\
\hline Modulus of Elasticity & $70 \mathrm{GPa}$ \\
\hline Thermal Conductivity & $180 \mathrm{~W} / \mathrm{m} . \mathrm{K}$ \\
\hline Electrical Resistivity & $0.038 \times 10^{\wedge}-6 \Omega . \mathrm{m}$ \\
\hline Density & $2.70 \mathrm{~g} / \mathrm{cm}^{3}$ \\
\hline Melting Point & $555^{\circ} \mathrm{C}$ \\
\hline Thermal Expansion & $24 \times 10^{\wedge}-6 / \mathrm{K}$ \\
\hline Proof Stress & $255 \mathrm{Min} \mathrm{MPa}$ \\
\hline Tensile Strength & $300 \mathrm{Min} \mathrm{MPa}$ \\
\hline Elongation A50 $\mathrm{mm}$ & $9 \mathrm{Min} \%$ \\
\hline Hardness Brinell & $91 \mathrm{HB}$ \\
\hline
\end{tabular}

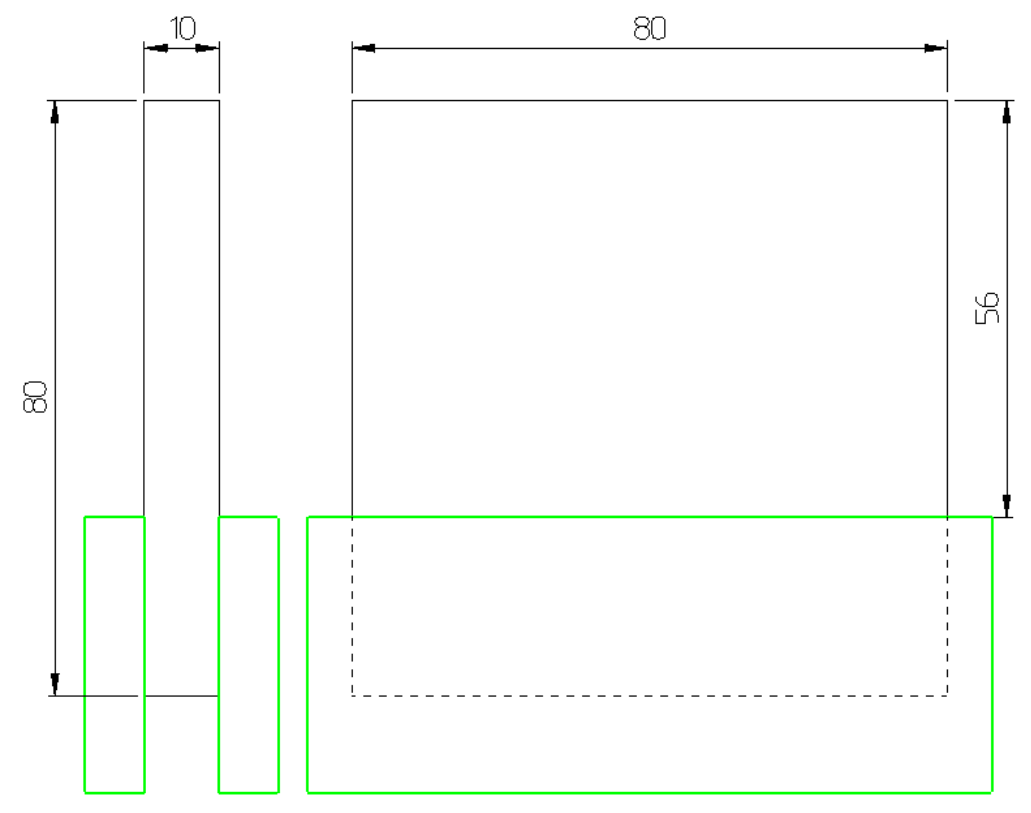

Fig. 3 Drawing of the blank (black colour) and the clamping jaws (green colour)

The thin-walled parts were milled only from one side. Figure 4 shows the final shape of the thin-walled part after milling. 


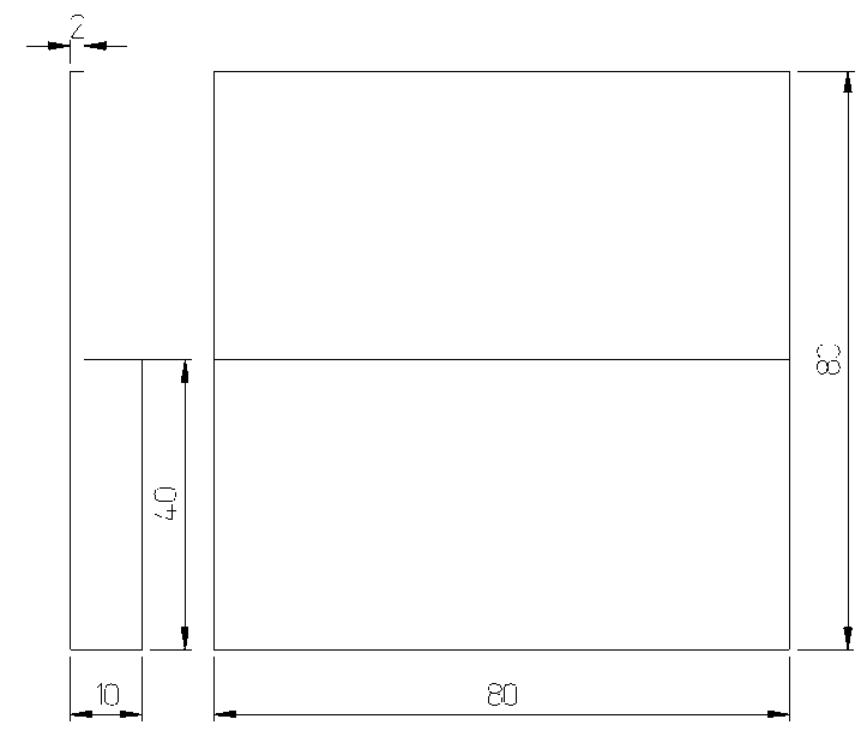

Fig. 4 Final shape and dimensions of thin-walled parts after milling

The experiment was carried out using HSC 105 linear CNC 5-axis machine. Table 1 shows the machining parameters used in the experiment. The cutting zone was cooled by cold compressed air.

\begin{tabular}{|l|c|}
\hline Table 4: Machining parameters \\
\hline Parameters & Value \\
\hline Cutting speed $-\mathrm{v}_{\mathrm{c}}$ & $800,1000,1200 \mathrm{~m} \cdot \mathrm{min}^{-1}$ \\
\hline Frequency $-\mathrm{n}$ & \begin{tabular}{c}
$1221,26526,31831 \mathrm{~min}^{-}$ \\
\hline Feed per tooth $-\mathrm{f}_{\mathrm{z}}$
\end{tabular} \\
\hline Deep of cut, roughing $-\mathrm{a}_{\mathrm{p}}$ & $10.12 \mathrm{~mm}$ \\
\hline Deep of cut, finishing $-\mathrm{a}_{\mathrm{p}}$ & $5 \mathrm{~mm}$ \\
\hline Width of cut, roughing $-\mathrm{a}_{\mathrm{e}}$ & $3,2.5,1.5 \mathrm{~mm}$ \\
\hline Width of cut, finishing $-\mathrm{a}_{\mathrm{e}}$ & $0.5,0.5 \mathrm{~mm}$ \\
\hline
\end{tabular}

The progressive radial depth of cut (RDOC) strategy was used (Fig. 5). The method of material removal according to RDOC is usually used for milling of parts with medium height and thickness ratio $<30: 1$. For the studied samples, the ratio was 20:1. Toolpaths and NC programs were generated using Autodesk PowerMILL software. 


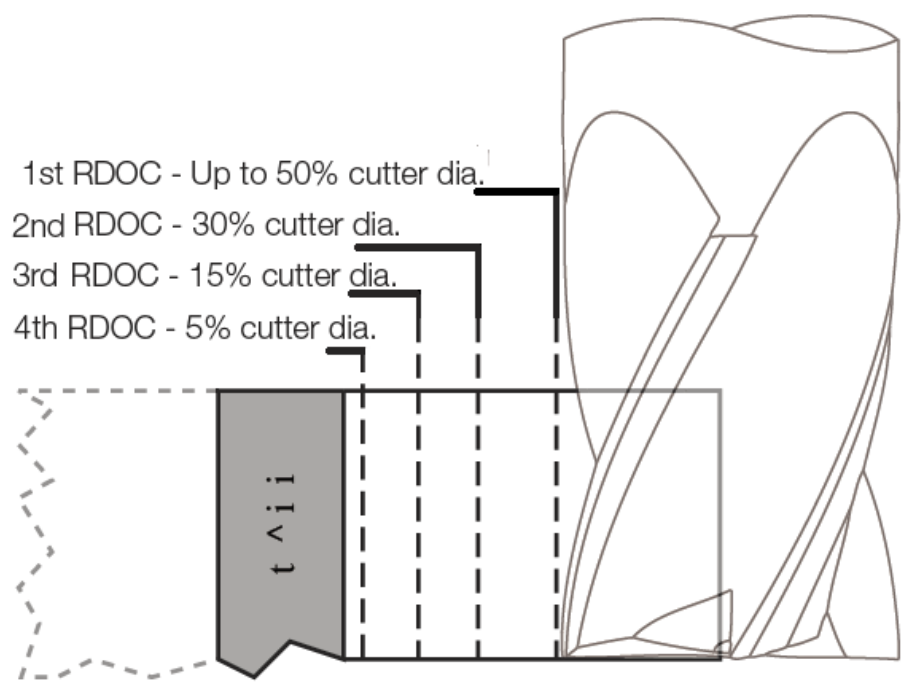

Fig. 5 RDOC milling strategy (12)

The surface quality and flatness were measured by GOM Atos II TripleScan optical 3D scanner. The measuring volume MV 170 (170 x $130 \times 130)$ was used for scanning the aluminium thin-walled parts. The chalk spray was applied to eliminate shiny surface. Surface quality was evaluated by the colour deviation maps and flatness. Fig. 6 shows the method of evaluation of the surface quality, which is based on surface comparison (CAD model vs. 3D Scan). That method was completely described in the following paper (8).

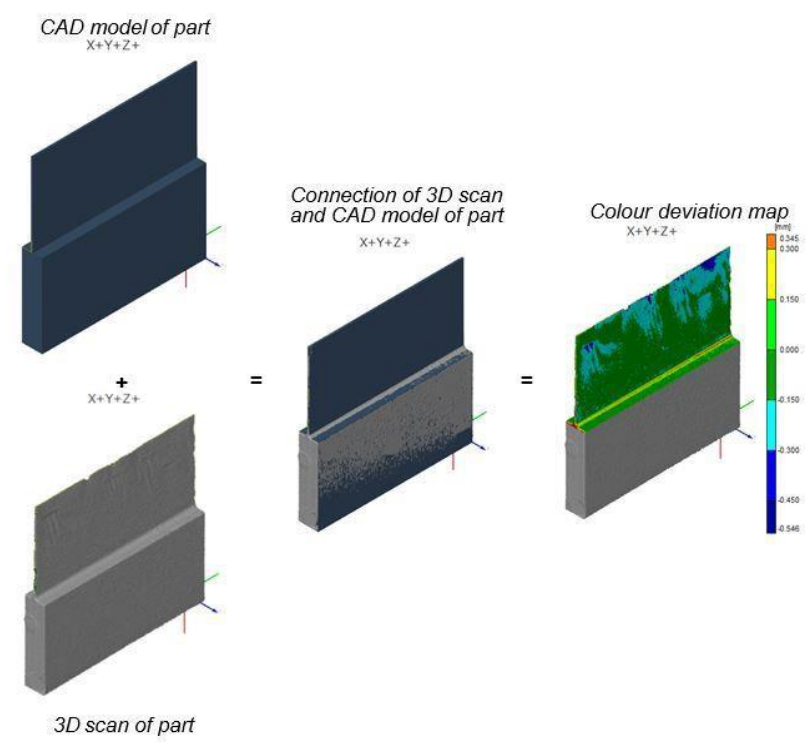

Fig. 6 Scheme of colour deviation map development (8)

\section{RESULTS AND DISCUSSION}

The machined surface of thin-walled parts can be seen in Fig. 7. In the case of workpieces, which were milled using end mill with constant $30^{\circ}$ helix angle for all three teeth (Fig. 7a-c) the tool marks are visible. The significant tool marks can be seen mainly when the higher cutting speeds were used, specifically1000 and $1200 \mathrm{~m} \cdot \mathrm{min}^{-1}$. 
The thin walled workpieces which were machined using end mills with adjusted helix angle of third tooth, the finer surface and smaller tool marks are visible (Fig. $7 \mathrm{~d}-\mathrm{i}$ ) in compared with surface milled by end mill with constant helix angle. In this case the using of cutting speeds 1000 and $1200 \mathrm{~m} \cdot \mathrm{min}^{-1}$ do not affected size of tool marks after milling, so that it is possible to use higher cutting speed in milling using end mill with different helix angle without decrease of the surface quality of aluminium thin walled parts.

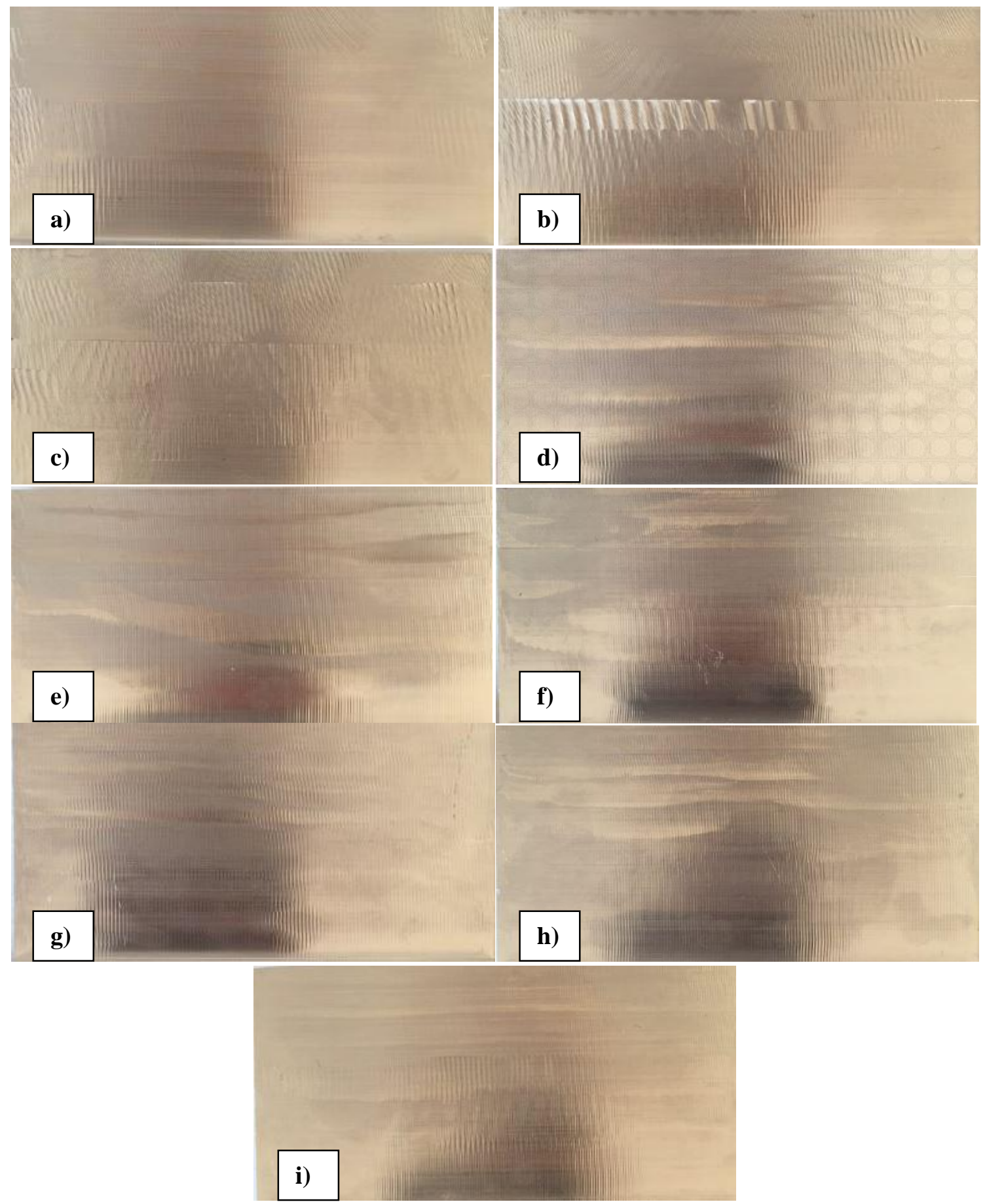

Fig. 7 Machined surface of thin walled part after milling using end mill $30^{\circ}$ and cutting speed $800 \mathrm{~m} \cdot \mathrm{min}^{-1}$ (a), $1000 \mathrm{~m} \cdot \mathrm{min}^{-1}$ (b) $1200 \mathrm{~m} \cdot \mathrm{min}^{-1}$ (c); using end mill with $25^{\circ}$ helix angle of third tooth and cutting speed $800 \mathrm{~m} \cdot \mathrm{min}^{-1}$ (d), $1000 \mathrm{~m} \cdot \mathrm{min}^{-1}$ (e) $1200 \mathrm{~m} \cdot \mathrm{min}^{-1}$ (f); using end mill with $35^{\circ}$ helix angle of third tooth and cutting speed $800 \mathrm{~m} \cdot \mathrm{min}^{-1}(\mathrm{~g}), 1000 \mathrm{~m} \cdot \mathrm{min}^{-1}(\mathrm{~h}) 1200 \mathrm{~m} \cdot \mathrm{min}^{-1}(\mathrm{i})$ 
Figs. 8-16 show colour deviations maps between a 3D scan of the machined thin walled parts and a 3D CAD model. The surface quality was evaluated by colour deviations maps and flatness of thin wall. Table 5 shows flatness of thin-walled parts. Colour deviations maps in Figs. 8-10 show that the use of end mill with constant $30^{\circ}$ helix angle in the milling of thin walled parts causes significant surface deviations which are even larger using higher cutting speeds 1000 and $1200 \mathrm{~m} . \mathrm{min}^{-1}$.In the case of using end mill with constant helix angle, the deviations and flatness were the smallest at cutting speed $800 \mathrm{~m} . \mathrm{min}^{-1}$, which is in accordance with well-known theory that in the milling of thin walled parts it is suitable to use lower cutting speed.

The colour deviations maps when end mills with different helix angle was used is showed in Fig. 7-12 and it shows significant decrease of surface deviations and flatness in compared with use end mill with constant helix angle, what can be even $50 \%$ in some cases. Simultaneously, the increase of cutting speed causes only minor increase of surface deviations and even using end mill with $35^{\circ}$ helix angle of third tooth and cutting speed $1000 \mathrm{~m} \cdot \mathrm{min}^{-1}$ the best result were obtained, which means the deviations between 3D scan of machined parts and 3D CAD model were the smallest and the flatness was $0.06 \mathrm{~mm}$. It follows that the use of end mills with different helix angle can significantly improves surface quality of thin walled part even at use of the higher cutting speed.

\begin{tabular}{|c|c|}
\hline \multicolumn{2}{|c|}{ Table 5: Flatness of thin-walled parts } \\
\hline $\begin{array}{c}\text { Cutting speed and Helix } \\
\text { angle }\end{array}$ & Flatness \\
\hline $800 \mathrm{~m} \cdot \mathrm{min}^{-1}-30^{\circ}$ & $0 ., 20$ \\
\hline $1000 \mathrm{~m} \cdot \mathrm{min}^{-1}-30^{\circ}$ & 0.28 \\
\hline $1200 \mathrm{~m} \cdot \mathrm{min}^{-1}-30^{\circ}$ & 0.24 \\
\hline $800 \mathrm{~m} \cdot \mathrm{min}^{-1}-25^{\circ}$ & 0.10 \\
\hline $1000 \mathrm{~m} \cdot \mathrm{min}^{-1}-25^{\circ}$ & 0.15 \\
\hline $1200 \mathrm{~m} \cdot \mathrm{min}^{-1}-25^{\circ}$ & 0.16 \\
\hline $800 \mathrm{~m} \cdot \mathrm{min}^{-1}-35^{\circ}$ & 0.10 \\
\hline $1000 \mathrm{~m} \cdot \mathrm{min}^{-1}-35^{\circ}$ & 0.08 \\
\hline $1200 \mathrm{~m} \cdot \mathrm{min}^{-1}-35^{\circ}$ & 0.13 \\
\hline
\end{tabular}

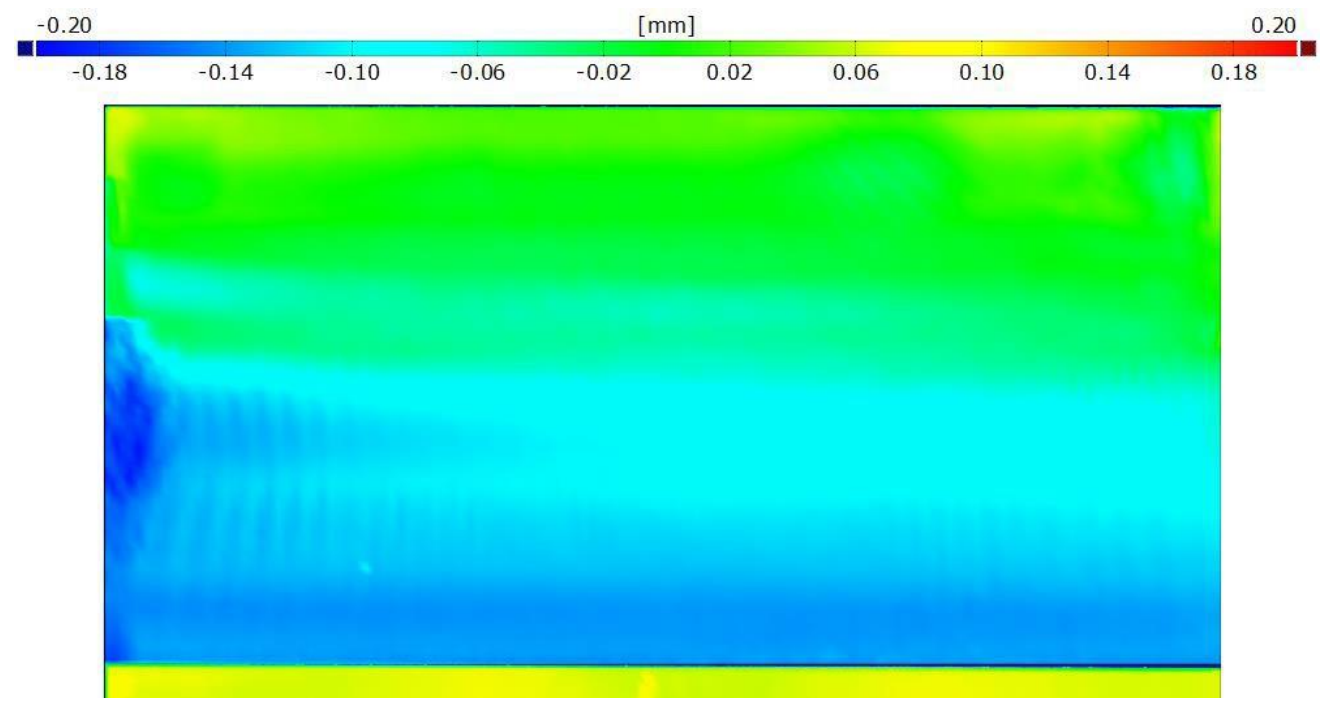

Fig. 8 Colour deviation map for D12-30,$v_{c}=800 \mathrm{~m} \cdot \mathrm{min}^{-1}$ 


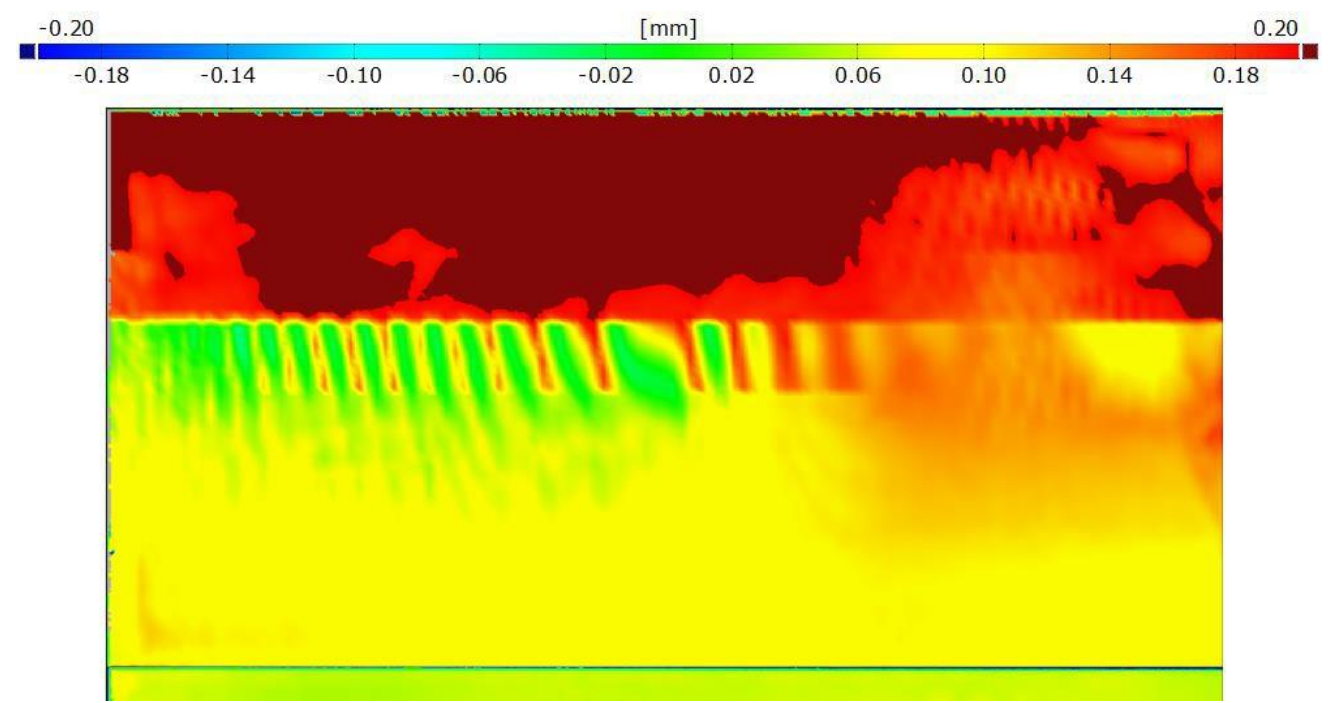

Fig. 9 Colour deviation map for D12-30 , $v_{c}=1000 \mathrm{~m} \cdot \mathrm{min}^{-1}$

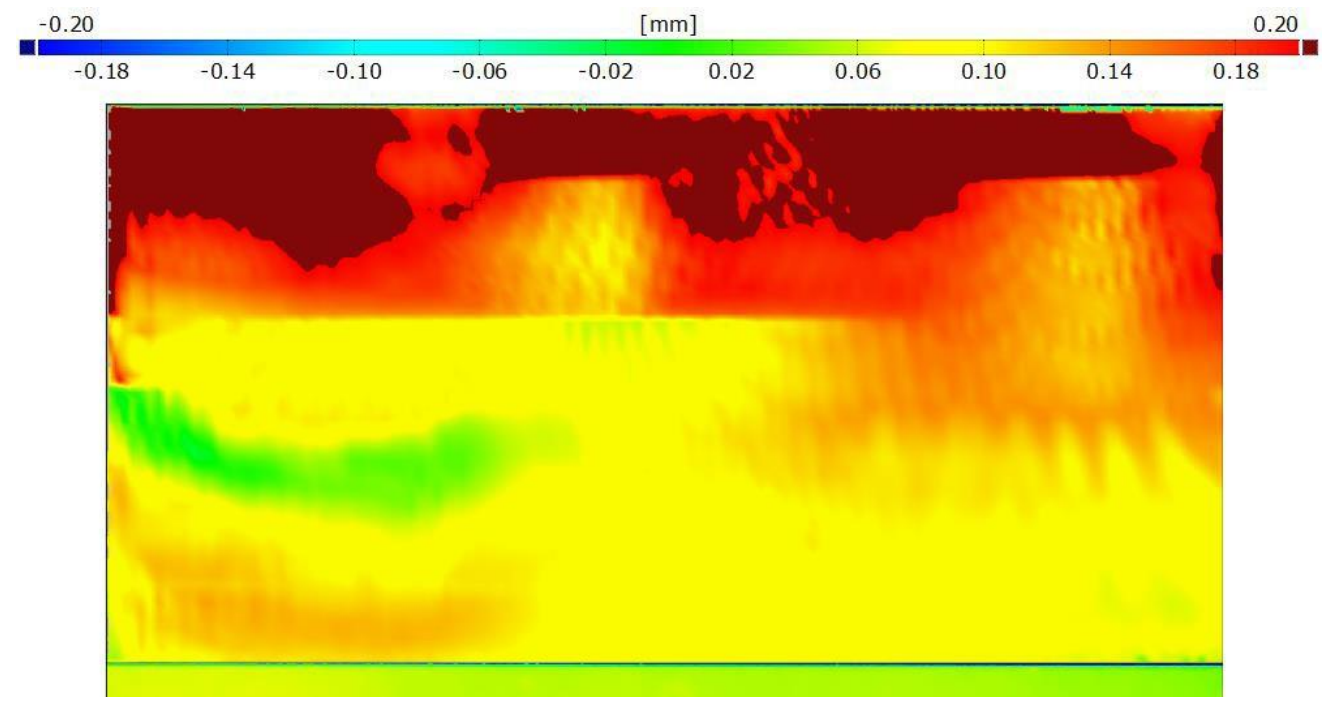

Fig. 10 Colour deviation map for D12-30,$v_{c}=1200 \mathrm{~m} \cdot \mathrm{min}^{-1}$

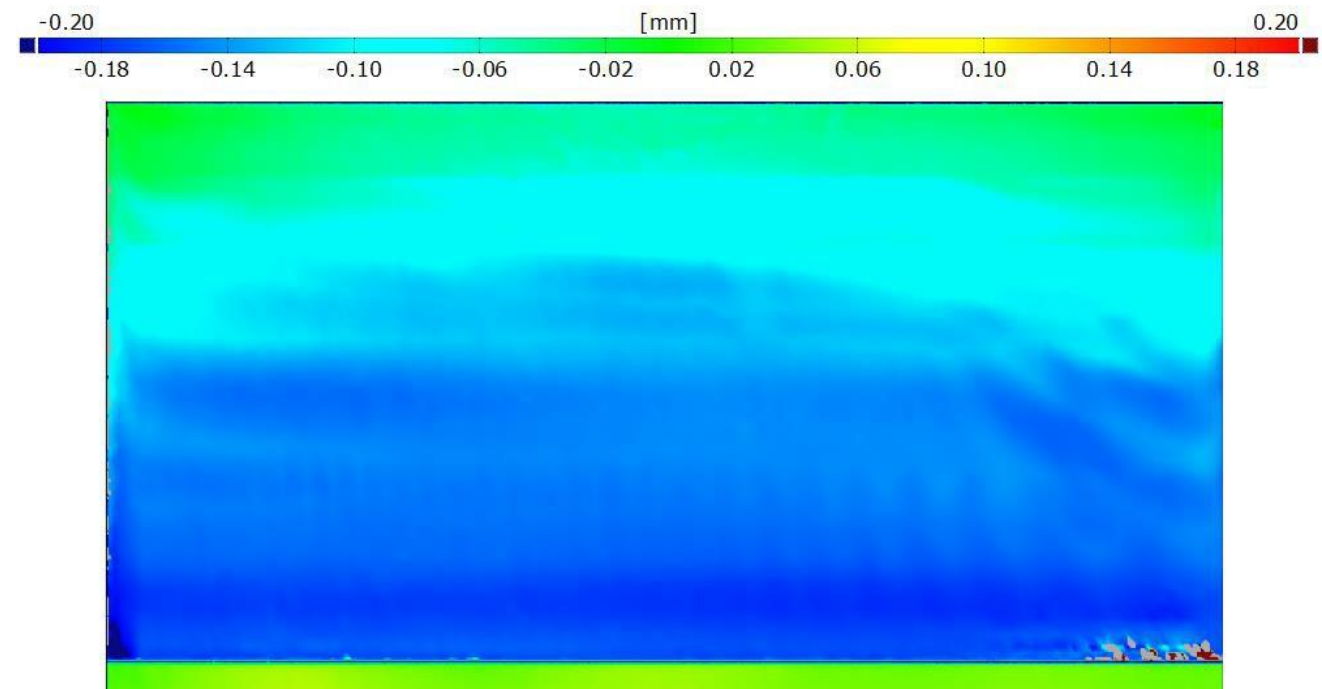

Fig. 11 Colour deviation map for D12-25 , $v_{c}=800 \mathrm{~m} \cdot \mathrm{min}^{-1}$ 


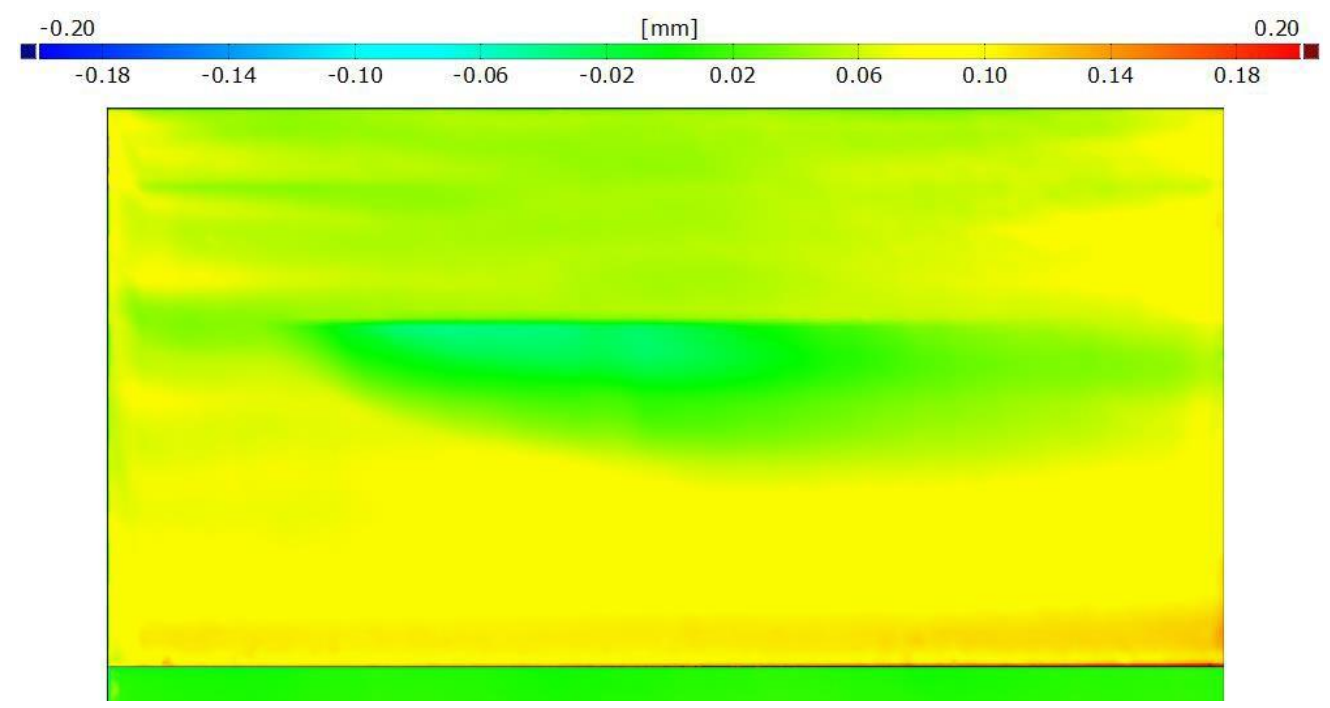

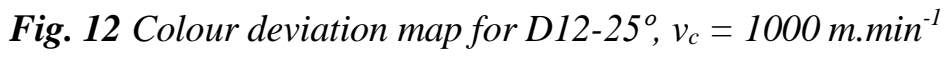

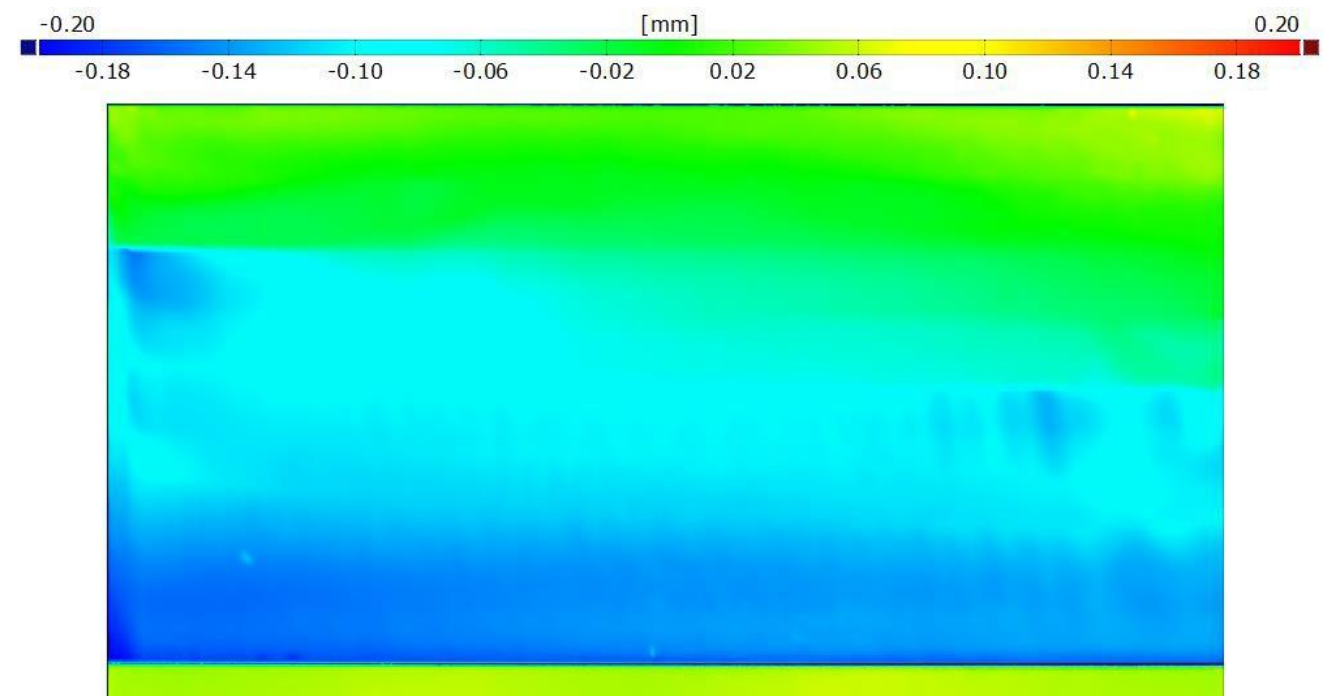

Fig. 13 Colour deviation map for D12-25,$v_{c}=1200 \mathrm{~m}^{\circ} \mathrm{min}^{-1}$

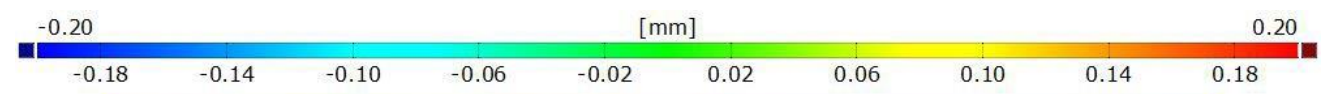

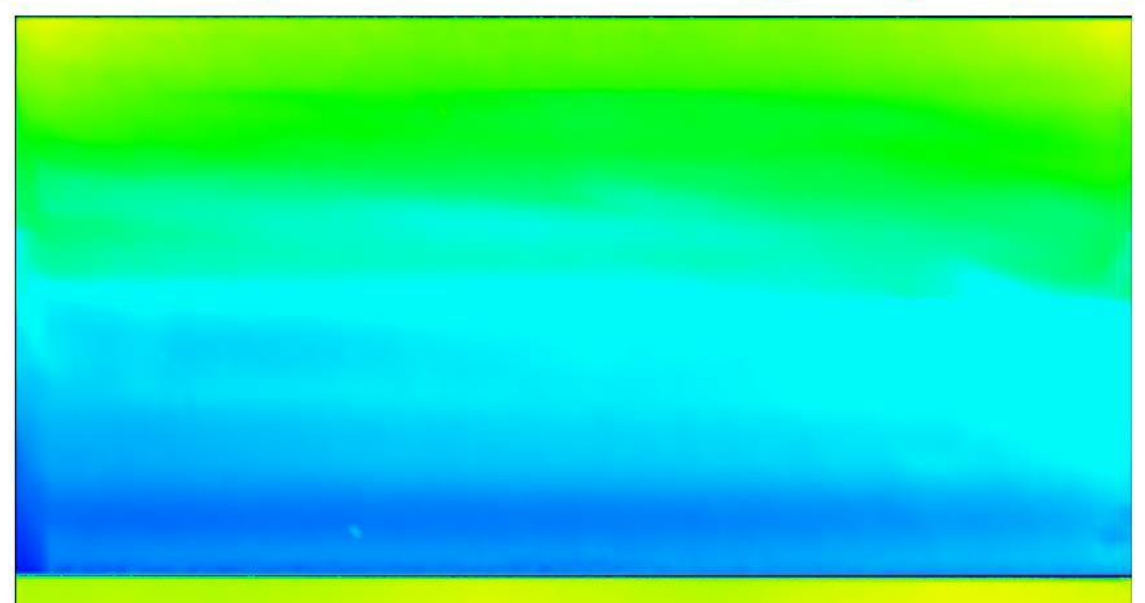

Fig. 14 Colour deviation map for D12-35,$v_{c}=800 \mathrm{~m} \cdot \mathrm{min}^{-1}$ 


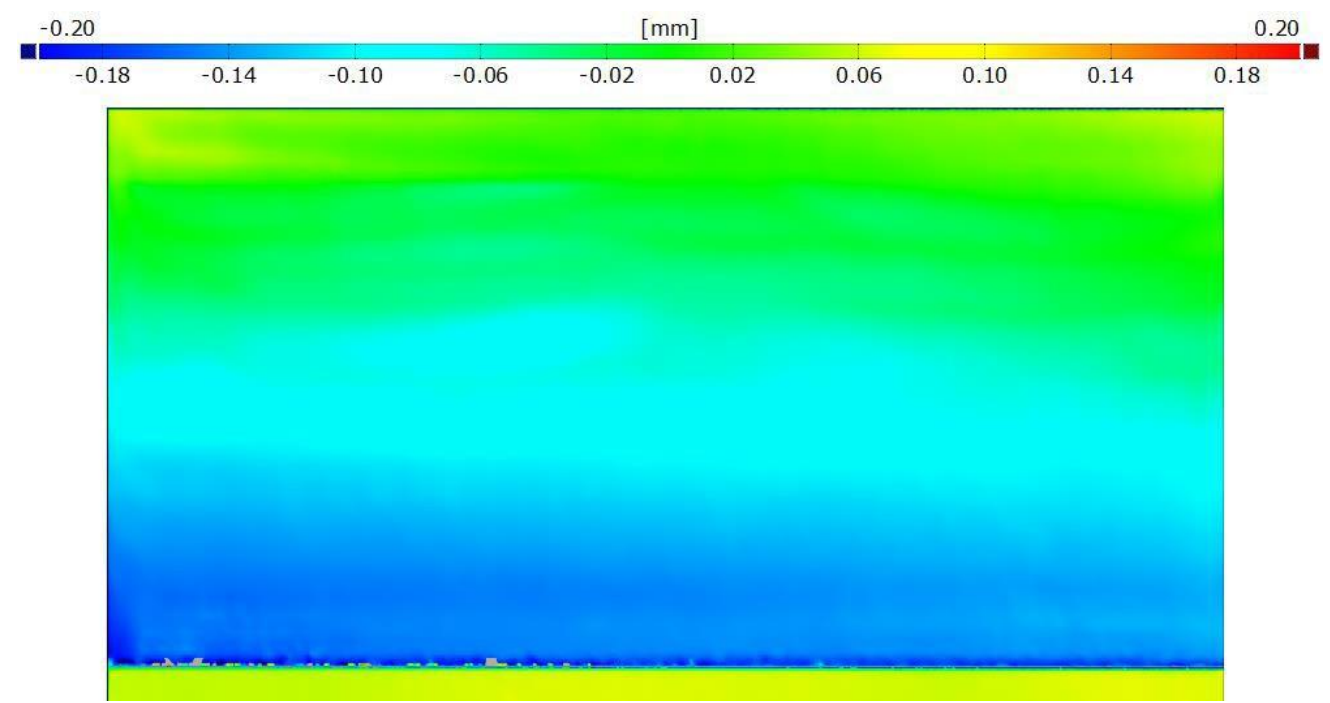

Fig. 15 Colour deviation map for D12-35,$v_{c}=1000 \mathrm{~m} \cdot \mathrm{min}^{-1}$

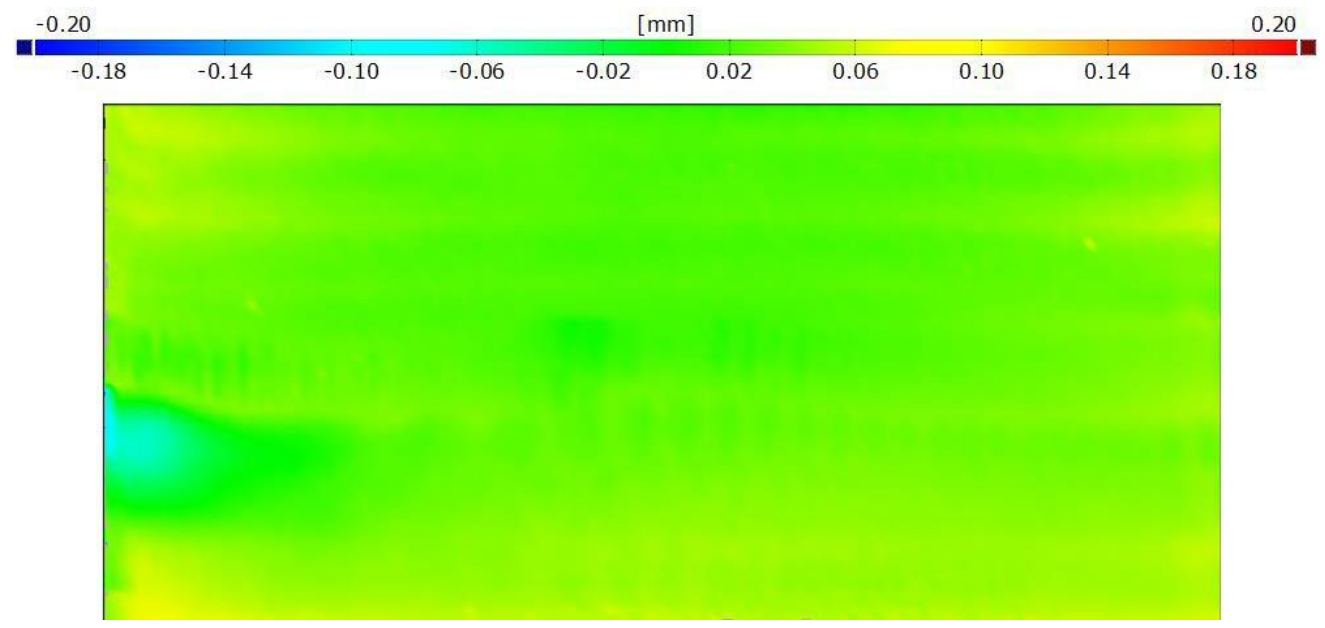

Fig. 16 Colour deviation map for D12-35 , $v_{c}=1200 \mathrm{~m} \cdot \mathrm{min}^{-1}$

\section{CONCLUSION}

The present paper describes the influence of helix angle of the end mills on surface quality and flatness of the processed aluminium thin-walled parts. It was shown that the different helix angle of third tooth of end mill has significant influence on surface quality and flatness. Use of the end mills with previous mentioned design reduces the chatter during milling process of the thin-walled parts. The experiment proved that the use of lower cutting speeds during the machining led to the surface quality improvement of the thin-walled parts. However, the best results of flatness and surface deviations were obtained after milling by end mills of $35^{\circ}$ helix angle of third tooth at higher cutting speed $1000 \mathrm{~m} . \mathrm{min}^{-1}$, so that based on the results in the case of end mills of different helix angle it is possible to increase cutting speed.

\section{Acknowledgements}

The support of the Project of VEGA grant agency of the Ministry of Education, Science, Research and Sport of the Slovak Republic and Slovak Academy of Sciences, no. 1/0097/17: "The research of novel method for cutting edge preparation to increase the tool performance 
in machining of difficult-to-machine materials as well as the APVV Project of Slovak Research and Development Agency of the Ministry of Education, Science, Research and Sport of the Slovak Republic, no. APVV-16-0057: "Research into the Unique Method for Treatment of Cutting Edge Microgeometry by Plasma Discharges in Electrolyte to Increase the Tool Life of Cutting Tools in Machining of Difficult-to-Machine Materials is acknowledged.

\section{References:}

1. KOVÁČ, M., BURANSKÝ, I. 2013. Experimental determination of milling model for thinwalled parts. ACTA TECHNICA CORVINIENSIS - Bulletin of Engineering, Tome VI, pp. 123126.

2. MASMALI, M., MATHEW, P. 2017. An analytical approach for machining thin-walled workpieces. Procedia CIRP, 58, pp. 187-192.

3. AIJUN, T., ZHANQIANG L., MA HAILONG. 2008. Modelling and Simulation of Big Deformations of Thin walled Plate in End Milling Process. [Online]. [cit. 2013-02-25]. http://www.sciencedirect.com/

4. COMAK, A., BUDAK, E. 2017. Modelling dynamics and stability of variable pitch and helix milling tools for development of a design method to maximize chatter stability. PRECISION ENGINEERING, vol. 47, pp. 459-468.

5. ALTINTAS, Y., BUDAK, E. 1995. Analytical prediction of stability lobes in milling. Ann CIRP, 44, pp. 357-362.

6. ALTINTAS, Y., SHAMOTO, E., LEE, P., BUDAK, E. 1999. Analytical prediction of stability lobes in ball end milling. Trans ASME J Manuf. Sci. Eng, 121, pp. 586-592.

7. BURANSKÝ, I. 2011. Thin-Walled Parts Machining. 1st Edition. - Köthen: Hochschule Anhalt, 84 p. ISBN 978-3-86011-043-0.

8. BARANEK, I., BURANSKÝ, I., PETERKA, J. 2013. Influence of material removal way on thinwalled part quality by milling. MM Science Journal, pp. 414-417.

9. ALTINTAS, Y., ENGIN, S., BUDAK E., 1999. Analytical Stability Prediction and Design of Variable Pitch Cutters. J. Manuf. Sci. Eng, 121(2), p. 6, pp. 173-178.

10. SANDVIKCOROMANT, 2018. Silent Tools for milling, Sandvik Coromant. [Online]. [cit. 2018-02-10]. https://www.sandvik.coromant.com/en-b/products/silent_tools_milling

11. SHAMOTO, E., SAITO, A. 2016. A novel deep groove machining method utilizing variablepitch end mill with feed-directional thin support. Precision Engineering, vol. 43, pp. 277-284.

12. HELICAL SOLUTIONS LLC. Thin wall milling, Helical Solutions LLC, 2018. [Online]. [cit. 2018-1-12]. http://www.helicaltool.com/secure/Content/Documents/Tech_ThinWallMilling.pdf

13. MATSUBARA, A., TANIYAMA, Y., WANG, J., KONO, D. 2017. Design of a support system with a pivot mechanism for suppressing vibrations in thin-wall milling, CIRP Annals, 1(66), pp. 381-384.

14. SUZUKI, N., ISHIGURO, R., KOJIMA, T. 2016. Design of irregular pitch end mills to attain robust suppression of regenerative chatter. CIRP Annals, 65(1), pp. 129-132.

15. YUSOFF, A. R. 2016. Identifying bifurcation behavior during machining process for an irregular milling tool geometry. Measurement, Volume 93, pp. 57-66.

\section{ORCID:}

$\begin{array}{ll}\text { Matej Bračík } & \text { 0000-0002-3644-6421 } \\ \text { Vladimír Šimna } & 0000-0001-7489-2441\end{array}$ 